
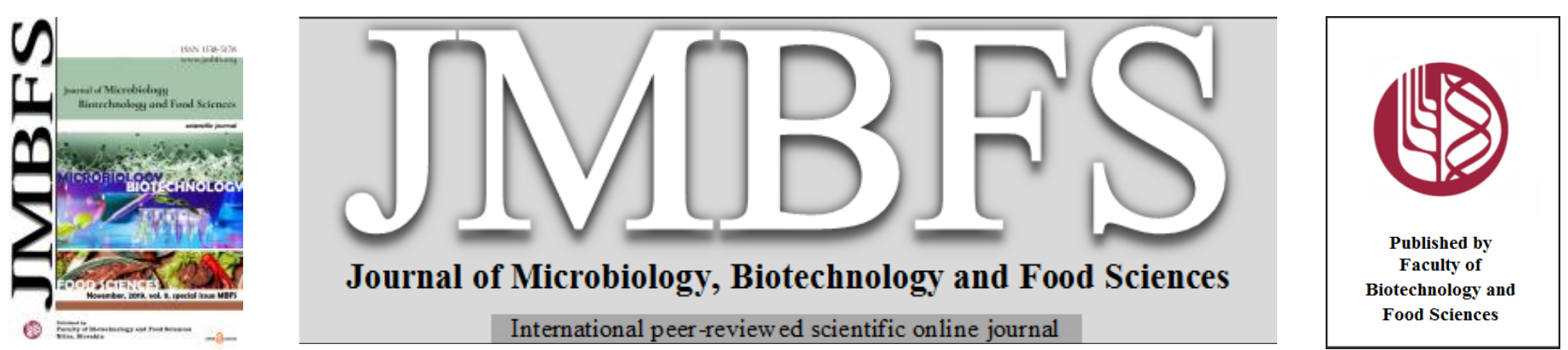

\title{
PROTEIN PROFILES OF CEREALS AND PSEUDOCEREALS DETERMINED BY TWO-DIMENSIONAL GEL ELECTROPHORESIS
}

\author{
Zdenka Gálovál, Želmíra Balážovál ${ }^{*}$, Dana Rajnincová ${ }^{1}$, Milan Chňapek ${ }^{1}$, Andrea Špalekovál, Andrea Hricová2 \\ Jana Žiarovská
}

\author{
Address(es): assoc. prof. Želmíra Balážová, PhD. \\ ${ }^{1}$ Department of Biochemistry and Biotechnology, Faculty of Biotechnology and Food Sciences, Slovak University of Agriculture, Tr. A. Hlinku 2, SK-94976 Nitra, \\ Slovak Republic. \\ ${ }^{2}$ Institute of Plant Genetics and Biotechnology, Slovak Academy of Sciences, 2, Akademicka, SK-94901 Nitra, Slovak Republic. \\ ${ }^{3}$ Department of Genetics and Plant Breeding, Faculty of Agrobiology and Food Resources, Slovak University of Agriculture, Tr. A. Hlinku 2, SK-94976 Nitra, Slovak \\ Republic.
}

*Corresponding author: Zelmira.Balazova@uniag.sk

doi: 10.15414/jmbfs.2019.9.special.359-365

\section{ARTICLE INFO}

Received 16. 7. 2019

Revised 4. 9. 2019

Accepted 27.9. 2019

Published 8. 11. 2019

Regular article

open 2 ACCESS

\begin{abstract}
The aim of this work was to determine the presence of celiac active proteins in wheat, barley, rye, oats, amaranth and buckwheat by creating of proteome profies application two-dimensional gel electrophoresis (2-DE). It has been found, that 2-DE protein profiles of pseudocereals had large differences compared to 2-DE profiles of cereals, mainly due to their inclusion in different botanical species (cereals, pseudocereals). Proteins with a molecular weight ranging from $40 \mathrm{kDa}$ to $200 \mathrm{kDa}$ and isoelectric points (pI) in the range of 911 were not been detected on the protein profiles of pseudocereals, while on the cereal protein profiles they were visible and corresponded to gluten proteins. On the other hand, some similarity was found between the chemical properties of amaranth and buckwheat, where most of the extracted proteins had a pI in the range of 5 to 10 and a molecular weight ranged from $14 \mathrm{kDa}$ to $55 \mathrm{kDa}$. The obtained 2-DE protein profiles confirm, that amaranth and buckwheat have none or only minimal content of gluten proteins, and therefore they are a good source for the production of foodstuffs intended for the consumption by people suffering from celiac disease.
\end{abstract}

Keywords: wheat; barley; rye; oats; amaranth; buckwheat; protein profiles

\section{INTRODUCTION}

Grains from cereals are a very important source of energy and nutrients in human and animal nutrition. Of all the seeds in the plant kingdom, only the wheat grain contains gluten proteins, which are capable of forming elastic dough that is required to bake leavened bread. These gluten proteins are also needed to make the great variety of foods that are associated with wheat around the world. The gluten complex, which forms during the mixing of wheat flour with water, is composed primarily of gliadin and glutenin. Glutenin is considered to confer the elasticity and gliadin the extensibility, or viscous flow properties, to dough.

The gluten fraction of wheat flour is the main cause of the development of celiac disease (CD). CD, gluten-sensitive enteropathy, is a permanent intolerance to gluten prolamins in wheat (gliadins), barley (hordeins) and rye (secalins) for predisposed individuals. Pure oat is considered with gluten-containing cereals during storage or processing. CD is caused by a faulty immune response to dietary wheat gluten (Shewry et al., 2002; Shewry, 2006; Londono et al., 2013; Ludvigsson et al., 2013).

Prolamin fractions mainly contain monomeric proteins, and glutelin fractions contain mainly polymeric proteins linked by interchain disulfide bonds. According to common structures, the storage proteins of CD toxic cereals have been classified into three groups: (1) high molecular weight (HMW); (2) medium molecular weight (MMW) and (3) low molecular weight (LMW) - the latter being the major group (Shewry, 2006). The proteins of these groups can be divided into different types on the basis of sequence homologies. The HMW group contains HMW glutenin subunits (HMW-GS) (wheat), HMW secalins (rye) and D-hordeins (barley). HMW-GS and HMW secalins can by subdivided into the x-type and $\mathrm{y}$ type and the molecular weights of the subunits have a range of 70000-90000 Daltons. Their amino acid compositions are characterised by high contents of glutamine, glycine and proline, which together account for cca $70 \%$ of total residues (Shewry et al., 1992; Shewry, 2006;). The MMW group consists of the homologous col, 2-gliadins (wheat), co-secalins (rye), C-hordeins (barley), and the unique co5gliadins (wheat). They have extremely unbalanced amino acid compositions, characterised by high contents of glutamine, proline and phenylalanine, which together account for approximately $80 \%$ of total residues and most regions of the amino acid sequences are composed of repetitive units such as (Q)QPQQPFP or (Q)QQQFP (Shewry et al., 2009). The LMW group can be divided into monomeric proteins including $\alpha / \beta$ - and $\gamma$-gliadins (wheat), $\gamma$-40ksecalins (rye), $\gamma$-hordeins (barley), and avenins (oats), and into aggregated proteins including LMW-GS (wheat), $\gamma$-75k-secalins (rye), and B-hordeins (barley). All these proteins have an $\mathrm{N}$-terminal domain rich in glutamine, proline and aromatic amino acids (phenylalanine, tyrosine) and a C-terminal domain with a more balanced amino acid composition and with most of the cysteine residues (Wieser and Koehler, 2008).

Determination of individual gluten peptides responsible for toxicity and immunogenecity is very difficult because, gluten is a mixture of proteins that are closely related (Parnell and Ciclictira, 1999). Initially, the toxicity of a welldefined group of $\alpha / \beta$-type gliadins, called $\alpha$-gliadin, was established, by means of instillation into the small intestine, followed by biopsy (Wieser and Koehler, 2008). The toxicity of $\alpha$-gliadin was subsequently confirmed by in vitro organ culture tests. Later, both in vivo and in vitro studies implicated all gliadin fractions, with decreasing activity from $\alpha$ - to $\omega$ - gliadins, as instrumental in causing disease (Parnell - Ciclictira, 1999). The $\alpha$-gliadin is the most toxic fraction and this protein has a relative low molecular weight of approximately $30 \mathrm{kDa}$ (Shewry et al., 1992; Parnell - Ciclictira, 1999).

The search for the precipitating proteins of $\mathrm{CD}$ was mainly performed with wheat and oats (Shewry et al., 2009). Testing of rye and barley has been rather minimal, the strong similarities of their storage proteins with wheat gluten proteins, however, suggest that they may be capable in causing $\mathrm{CD}$. The taxonomy of the plants might provide useful guidance in dividing grains into safe and unsafe, regarding human consumption and $\mathrm{CD}$.

Some cereals (rice, maize and others) and pseudocereals (amaranth, buckwheat and quinoa), rich in proteins, do not contain gluten, which is the main cause of $\mathrm{CD}$ Recent findings suggest that Western diets based on highly palatable foods are likely to be much less satiating than more ethnic foods or those typical of less 
developed countries. In particular, some alternative crops (e.g. buckwheat, sorghum, quinoa, amaranth) seem to be of great nutritional interest and to represent important recipes for healthier and typical regional foods (Gorinstein et al., 2002). Therefore, in the last decade, the use of pseudocereals was increased not only in special diets for people allergic to cereals, but also in healthy diets. Comparative protein studies of cereals and pseudocereals are important, especially in cases of cereal protein allergy when pseudocereal substitution is unavoidable (Gorinstein et al., 2005). Gorinstein et al. (Gorinstein et al., 2005) analysed the relationship between dicotyledons (amaranth, quinoa, buckwheat, soybean) and monocots (sorghum and rice), based on protein analyses and their use as substitution of each other and found similarities between these plants, which could make them a substitute of each other as well as for cereals. They reported that combination and substitution of cereals by pseudocereals lead to nutritional foods and can prevent allergy. Food components may be promoters of positive metabolic mechanisms. Gupta (Gupta, 2004) says that a combination of cereals, pseudocereals and soybean provides protein-rich ingredients resulting in higher nutritive value. Two-dimensional gel electrophoresis (2-DE) has frequently been used to characterize the diversity of protein components in wheat (Jackson et al., 1983; Hurkman and Tanaka, 2004; Vensel et al., 2014). However, only since the end of 1990s have large-scale high-throughput proteomic approaches been applied to wheat grain proteins. Proteomic analyses exploit the availability of genome sequences to identify proteins based on the use of mass spectrometry to determine the masses of peptide fragments resulting from the tryptic digestion of small amounts of components separated by electrophoresis (Vensel $\boldsymbol{e t}$ al., 2014).

In the present study, the protein profiles of four types of cereals (wheat, barley, rye, oats) and two types of pseudocereals (amaranth, buckwheat) were determined by $2-\mathrm{DE}$.

\section{MATERIAL AND METHODS}

\section{Plant material}

The collection of four types of cereals (wheat - cv. Brea, barley - cv. Expres, rye cv. Oklon, oats - cv. Valentin) and two types of pseudocereals (amaranth - cv Plaisman, buckwheat - cv. Pyra) were used for analysis. Samples were obtained from the Gene Bank of the Research Institute of Plant Production (Piešt'any, Slovakia) and grains were milled by CU Mill ((Lionhill, London, United Kingdom) to a homogenous flour with particle size $0,2 \mathrm{~mm}$

\section{Samples preparation}

roteins were extracted from the flour of analysed cereals and pseudocereals by adding $1 \mathrm{ml}$ of buffer to $50 \mathrm{mg}$ of flour. The buffer contains dithiothreitol (DTT), immobilized $\mathrm{pH}$ gradient (IPG) buffer, ultra-pure water and IPG rehydration buffer (urea, thiourea, 3-[(3-cholamidopropyl)dimethylammonio]-1-propanesulfonate hydrate). The samples were then wheel-mixed for $120 \mathrm{~min}$ and centrifuged $3 \mathrm{~min}$ at $9000 \mathrm{xg}$. The proteins concentration in the supernatant was estimated by Coomassie Plus protein assay (Thermo Fisher Scientific, Waltham, Massachussets, USA) which was based on the Bradford assay (Bradford, 1976) and samples were stored at $-20{ }^{\circ} \mathrm{C}$ until use.

The Compact-Able Protein Assay Preparation Reagent Set (Thermo Fisher Scientific) was used to precipitate the proteins of the oat, which were then resuspended in the extraction buffer as described previously.

\section{Two-dimensional gel electrophoresis}

Two-dimensional protein profiles were prepared by standard method of the Institute of Food Research (Norwich, United Kingdom) according to modified method of Salt et al. (Salt et al., 2005).

\section{First dimension - isoelectric focussing (IEF):}

Immobilized $\mathrm{pH}$ gradient strips (GE Healthcare, Chicago, Illinois, USA) were rehydrated overnight at $20^{\circ} \mathrm{C}$ in $125 \mu \mathrm{l}$ of rehydration buffer containing $7 \mathrm{~mol} \cdot \mathrm{l}^{-1}$ urea; $2 \mathrm{~mol} \cdot \mathrm{l}^{-1}$ thiourea, $2 \%$ 3-[(3-cholamidopropyl)dimethylammonio]-1propanesulfonate hydrate; $0.5 \mathrm{~mol} \cdot 1^{-1}$ dithiothreitol; relevant $\mathrm{pH}$ range IPG buffer; $0.01 \mathrm{~g} \cdot \mathrm{l}^{-1}$ bromophenol blue. On the each strip, fourty micrograms of proteins were loaded. Isoelectric focusing was performed using $7 \mathrm{~cm}$ immobilized $\mathrm{pH}$ gradient strips with a pH range of 3-11 and 6-11 using the Protean IEF Cell (Bio-Rad, Hercules, California, USA). Focussing was performed at $20{ }^{\circ} \mathrm{C}$, current $50 \mu \mathrm{A}$ per strip. Focussed strips were stored at $-80{ }^{\circ} \mathrm{C}$ until required for the second dimension.

\section{Second dimension - polyacrylamide gel electrophoresis (SDS PAGE)}

Focussed strips were equilibrated in $52 \mathrm{mmol} \cdot \mathrm{l}^{-1}$ dithiothreitol with equilibration solution containing $0.5 \%$ sodium dodecyl sulfate; $6 \mathrm{~mol} \cdot \mathrm{l}^{-1}$ urea; $3 \%$ glycerol; 0,1 $\mathrm{g} \cdot \mathrm{l}^{-1}$ bromophenol blue and subsequently alkylated in $0.14 \mathrm{~mol} \cdot \mathrm{l}^{-1}$ iodoacetamide with equilibration solution. Separation of proteins was done on 4-12\% Bis-Tris Zoom gels (Invitrogen, Carlsbad, California, USA) at $100 \mathrm{~W}$ and $200 \mathrm{~V}$ per gel using 2-(N-morpholino) ethanesulfonic acid with sodium dodecyl sulfate buffer (Invitrogen). Gels were fixed in solution containing $40 \%$ methanol and $10 \%$ trichloroacetic acid overnight and then were stained with SYPRO Ruby Protein Gel Stain (Invitrogen). Gels were visualized using molecular imager PharosFX Plus System (Bio Rad) in three indipendent replicates for each sample.

\section{RESULTS AND DISCUSSION}

The total protein profiles of four types of cereals (wheat, barley, rye, oats) and two types of pseudocereals (amaranth, buckwheat) were obtained by performing 2-DE over a broad $\mathrm{pH}$ range $(\mathrm{pH} 3-11)$. Then, focussing on the gluten fraction, as it is the major trigger for celiac disease, we separated proteins with a basic pI over a narrow $\mathrm{pH}$ range of $\mathrm{pH}$ 6-11. Putative identifications of proteins were obtained using current literature for each type of crop (Rocher $\boldsymbol{e t ~ a l . , 1 9 9 2 ; ~ V a r j o n e n ~} \boldsymbol{e t}$ al., 1994; Rocher et al., 1996; James et al., 1997; Aalberse, 2000; Skylas et al., 2000; Finnie et al., 2002; Gellrich et al., 2003; Bak-Jensen et al., 2004; Østergaard et al., 2004; Perrocheau et al., 2005; Anderson and Wieser, 2006; Akagawa et al., 2007; Dupont et al., 2011; Londono et al., 2013; Vensel et al., 2014; Guo et al., 2016; Klubicová et al., 2016; Malalgoda and Simsek, 2017; Nałęcz et al., 2017; Zhou et al., 2018).

\section{Wheat}

The most abundant endosperm proteins from wheat identified in this work belong to the seed storage gliadin and glutenin families, alpha-amylase inhibitor and alpha-amylase/trypsin inhibitor families. Many proteins were focussed over $\mathrm{pH} 3$ 11 (Fig. 1) between 6000-120000 Da and the most abundant proteins in the basic region of the gel were observed; including three abundant proteins visible at approximately pI 7, $14000 \mathrm{Da}$ (marked as b). These corresponded to trypsin/alphaamylase inhibitors previously identified from the soluble fraction of wheat dough (Jackson et al., 1983; Salt et al., 2005; Vensel et al., 2014), as well as in immature wheat-grain endosperm proteins (Skylas et al., 2000; Dupont et al., 2011). A larger abundant protein group was visible between 36-55000 Da (marked as a) and these proteins were resolved at the correct mass and $\mathrm{pI}$ range for gluten, previously identified by Skylas et al. (Skylas et al., 2000), where a group of high molecular weight glutenin subunits with pI 5.5-6.5, 66-100000 Da and a group of omega gliadins with pI 5.0-6.0, 45-55000 Da were observed using 2-DE. This group is particularly important for $\mathrm{CD}$, so these basic proteins were separated over a narrower range of $\mathrm{pH} \mathrm{6-11(marked} \mathrm{as} \mathrm{c}$ ). It was obvious that these proteins were highly abundant as they were much better resolved and well-defined spots over this basic $\mathrm{pH}$ range ( $\mathrm{pH}$ 6-9) were achieved. These proteins formed a distinct pattern of spots allowing comparison with 2-D profiles of other cereal proteins. It was also observed, that the alpha-amylase/ trypsin inhibitors were better resolved in the basic region (marked as d). Although these proteins are not linked to $\mathrm{CD}$, they have been reported to trigger bakers asthma and have been linked to food allergy (James et al., 1997). The overall spot pattern from wheat (cv. Brea) over pH 6-11 was partially similar to those reported by other authors (Skylas et al., 2000; Akagawa et al., 2007; Dupont et al., 2011). These included proteins identified as gammagliadins $(\sim$ pI 8-10, molecular weight 28-30000 Da), alpha/beta-gliadins ( $\sim$ pI $6.5-$ 7.5 , molecular weight $25-35000 \mathrm{Da}$ ) and gluten proteins (pI 6-10, molecular weight 35 - $60000 \mathrm{Da}$ ). A cluster of polypeptides resolved at the end of $\mathrm{pH}$ 6-11 gel may be triticin ( pI 9.5-10, molecular weight $25000 \mathrm{Da}$, marked as e), a protein synthesis inhibitor, which was previously identified by Matrix Assisted Laser Desorption/Ionization time-of-flight mass spectrometry (MALDI-TOF-MS) analysis (Salt et al., 2005; Dupont et al., 2011; Vensel et al., 2014;) 

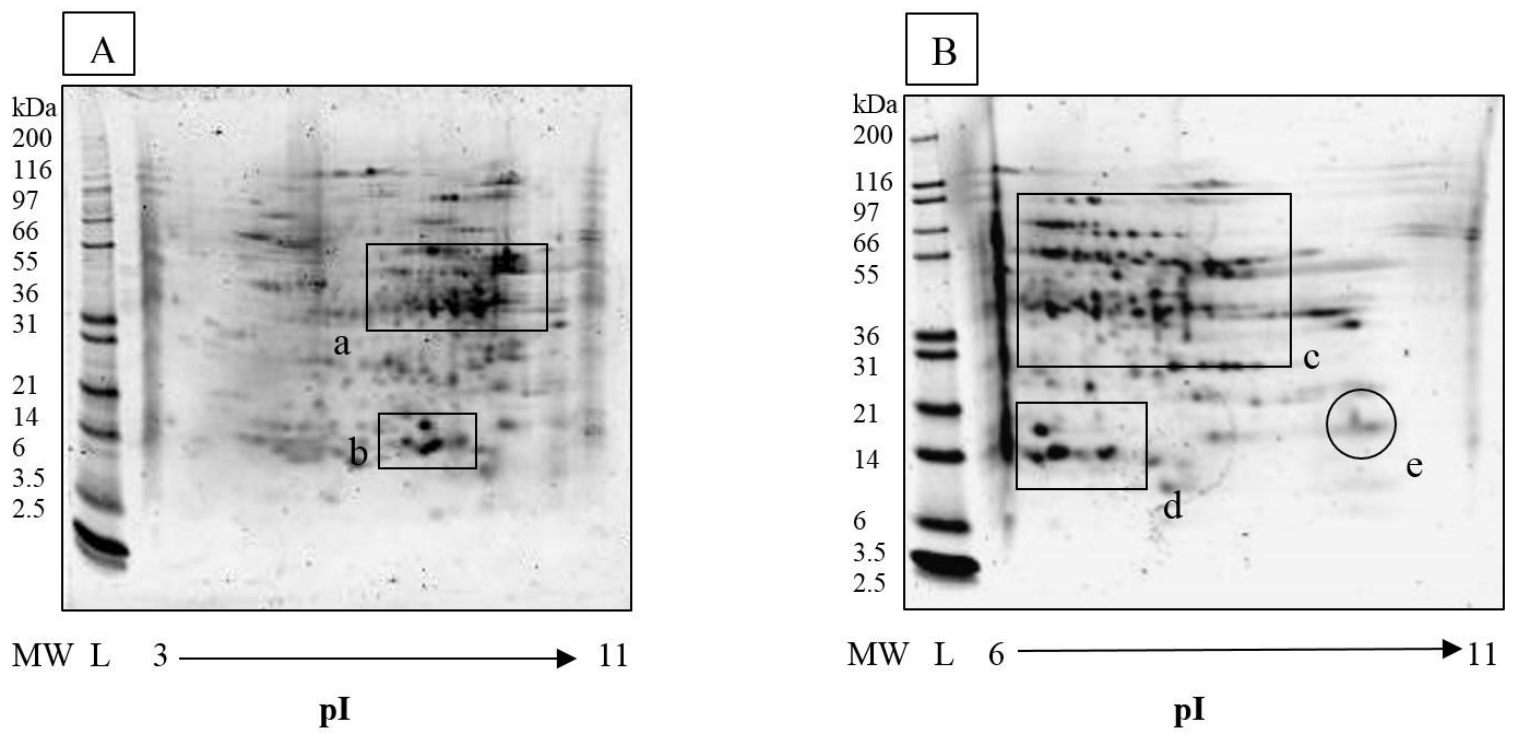

Figure 1 Protein profiles of wheat (cv. Brea)

Legend: A - gluten profile in immobilised pH gradients strips with pH 3-11; B - gluten profile in immobilised pH gradients strips with pH 6-11. MW [kDa] - molecular weight, L - ladder marker; a and c: high molecular weight glutenins and omega gliadins; $\mathrm{b}$ and d: alpha-amylase/ trypsin inhibitors family; e: triticin

Barley

Many spots of barley proteins were focussed between $\mathrm{pH} 3-11$, and the apparent molecular weights of the resolved proteins were between 6-200000 Da (Fig. 2). A group of intense spots of low molecular mass (6-21000 Da) and pI 4.5 of 5.5 (marked as a), were observed which corresponded to alpha-amylase/trypsin inhibitor proteins previously identified in developing barley seeds by Akagawa et al. (Akagawa et al., 2007), Finnie et al. (Finnie et al., 2002), Østergaard et al. (Østergaard et al., 2004), Perrocheau et al. (Perrocheau et al., 2005). A second group of alpha-amylase/trypsin inhibitor proteins have been previously identified with a low molecular weight range from 12-16000 Da and pI 5-7 (Bak-Jensen $\boldsymbol{e}$ al., 2004; Guo et al., 2016;) and could be the group of proteins highlighted between 12-21000 $\mathrm{Da}$ (marked as d, e)

Perrocheau et al. (Perrocheau et al., 2005) identified the hordeins and $12 \mathrm{~S}$ seed storage proteins, which were observed on both the $\mathrm{pH}$ 3-11 gel (marked as b) and 6-11 gels (marked as c) in the range of $35-45000 \mathrm{Da}$, in the pI 6-8 range. Specifically, spots observed at approximately $45000 \mathrm{Da}$, pI 8 should correspond to the B3 Hordein.

Bak-Jensen et al. (Bak-Jensen $\boldsymbol{e t}$ al., 2004) and Perrocheau et al. (Perrocheau $\boldsymbol{e}$ al., 2005) identified beta-glucosidase (45000 Da, pI 6.5), alcohol dehydrogenase (11000 Da and pI 8) and non-specific lipid-transfer protein (60-62000Da, pI 6-8). Glyceraldehyd-3-phosphate dehydrogenase (42000 Da and pI 7) could also be present according to identifications made by Bak-Jensen et al. (Bak-Jensen $\boldsymbol{e t} \boldsymbol{a l}$., 2004); these proteins may be present in highly populated areas of the gels making it difficult to determine by eye.

A protein visible at the very basic region on the $\mathrm{pH}$ 6-11 gel (marked as g) was also observed at a similar $\mathrm{pI}$ and mass on the wheat gel $(\sim \mathrm{pI} 9.5-10$, molecular

\section{A}

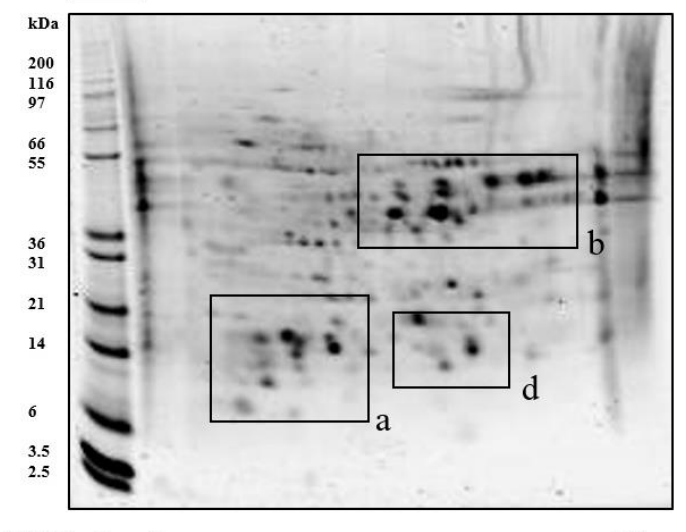

MW L 3 weight $25000 \mathrm{Da}$, (marked as e). This protein was focussed and resolved at the $\mathrm{pI}$ and mass corresponding to triticin (as described for wheat).

On the pH 3-11 gel (marked as b) an abundant region of spots was observed ranging from pI 6-9. Some protein spots appeared not-well defined with an irregular shape, or two spots very close to each other, indicating that at least two proteins were resolved at similar mass and pI, resulting in overlapping making it difficult to distinguish between proteins. Due to their position on the gel it was assumed that these proteins were the hordeins and were then separated over a $\mathrm{pH}$ range of 6-11 (marked as c). This separation allowed the visualisation of many more storage proteins than were visible over a broad range, and resolved the issue of proteins overlapping. The gluten proteins appeared as isoelectric streaks suggesting that they may have undergone post-translational modifications (PTM) The spot patterns of the gluten proteins from barley had similarities to the prolamins from wheat (marked as c). We could not assign any identifications to the group of intense unidentifiable protein spots of low molecular mass (10-20000 Da) and pI 6 of 8 (marked as f).

Guo et al. (Guo et al., 2016) identified 502 reproducible protein spots in barley seed proteome were detected with a $\mathrm{pH}$ range of 4-7 and 6-11. Thirty-four protein spots corresponding to 23 different proteins were identified, which were grouped into eight categories, including stress, protein degradation and post-translationa modification, development, cell, signaling, glycolysis, starch metabolism, and other functions. Malting quality is characterized by an accumulation of serpin protein, alpha-amylase/trypsin inhibitor $\mathrm{CMb}$ and alpha-amylase inhibitor BDAI1 (Guo et al., 2016).

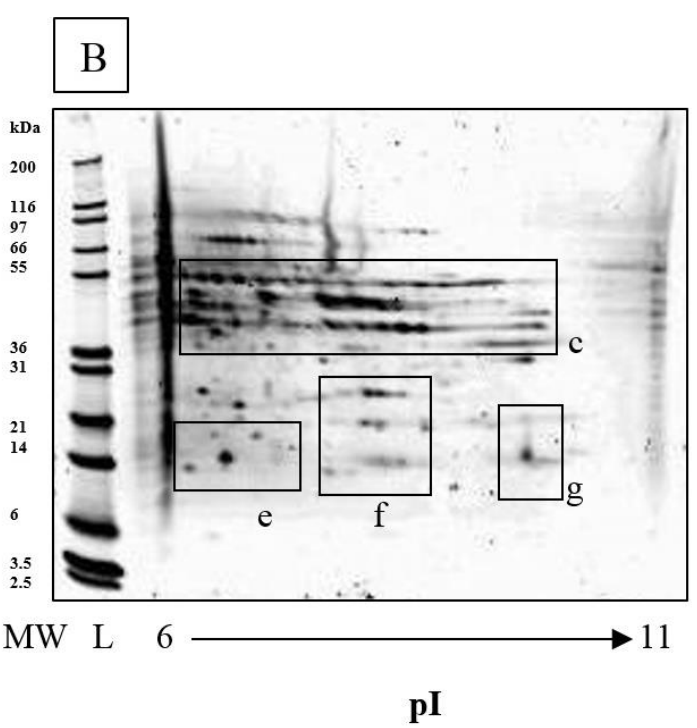

Figure 2 Protein profiles of barley (cv. Expres)

Legend: A - hordeins profile in immobilised $\mathrm{pH}$ gradients strips with $\mathrm{pH}$ 3-11, B - hordeins profile in immobilised $\mathrm{pH}$ gradients strips with $\mathrm{pH}$ 6-11. MW [kDa] - molecular weight, L ladder marker; a and d and e: alpha-amylase/ trypsin inhibitors family; b and c: $12 \mathrm{~S}$ hordeins, B3 hordeins; f: high molecular weight hordeins; g: triticin. 
Oats

Oat is primarily used as energy feed, since its grain has an excellent nutritional profile, that provides high-quality proteins, dietary fibres, carbohydrate, oil, minerals and low starch content. The proteins content in cultivated oat is about 12 $15 \%$, the major storage proteins are globulins, which are higher in essential amino acids than prolamin storage proteins. Oat proteins can be tolerated by most celiac individuals, making it an interesting raw material for the ever-expanding glutenfree market. The safety of oat for celiac patients is highly debated, and the varying outcomes regarding its toxicity could be due to variations in the protein sequences in different oat varieties and cultivars (Londono et al., 2013; Malalgoda and Simsek, 2017; Nałęcz et al., 2017).

The total protein profile from the oat extract was very different to wheat and barley, which shared some similarities (Fig. 3). Upon initial observation there appeared to be less proteins in oat with prominent areas of abundant proteins. Proteins were resolved between 6-116000 Da and focussed over the range of pI 5-9. A distinct train of abundant proteins was present at approximately $36-55000 \mathrm{Da}(\sim 38000 \mathrm{Da})$ pI 5-8 on both the pH 3-11 gel (marked as a) and pH 6-11 gel (marked as b). These highly abundant proteins probably corresponded to gluten proteins/ avenins (Malalgoda and Simsek, 2017). Major storage proteins of oats are avenins and globulins. The avenins are a highly polymorphic group with molecular weight 20 $30000 \mathrm{Da}$ and a minor group with molecular weight 30-40000 Da. The oat globulins consist of $12 \mathrm{~S}$ species, with molecular weight 330000 comprising six subunits of about molecular weight $55000 \mathrm{Da}$ and molecular weight $23000 \mathrm{Da}$ chains linked by S-S bonds. It is likely these are involved as allergens in oat. In the study of Varjonen et al. (Varjonen et al., 1994) oat allergic sera have cross-reacted with proteins from wheat, rye and barley. A $66 \mathrm{kDa}$ allergen was found in oat, but its sequence and protein family is still not known. It could be the group of proteins highlighted at approximately pI 6.5-8 and molecular weight $66000 \mathrm{Da}$ (marked as e). Two abundant spots located in the basic region of the $\mathrm{pH} 3-11$ gel (marked as c) and 6-11 gel (marked as d), were observed at approximately $14000 \mathrm{Da}, \mathrm{pI} 7$ similar spots were present for wheat (Fig. 1) and barley (Fig. 2) which corresponded to trypsin/alpha-amylase inhibitor proteins.

Rocher et al. (Rocher $\boldsymbol{e t}$ al., 1992) identified three major avenins, which react with celiac sera and that they called oat "celiac immunoreactive proteins" (CIP), as well as one alpha amylase inhibitor from oat endosperm, which showed a significant homology (60-80\% of identity) with the alpha amylase inhibitor from ragi, as well as with the two probable alpha amylase inhibitor from rice and barley. Avenin-A (CIP-1), which belongs to the gliadin/glutenin family and causes allergic reaction in human and are one of the cause of CD. It has theoretical pI 4.25 and molecular weight $4393 \mathrm{Da}$, as well as Avenin-F (CIP-2), which has theoretical pI 3.45 and molecular weight $5213 \mathrm{Da}$ and Avenin-E (CIP-3) with theoretical pI 7.44 and molecular weight $21000 \mathrm{Da}$, it could be highlighted protein spots with $\mathrm{pI}$ ranging from 7 to 8 and molecular weight 15-25000 Da (marked as f). Avenin-A and Avenin-F are not visible on our gels. We can not identified protein spots and compare our results very properly due to lack of information because there has been very little research done for oats, especially by 2-D electrophoresis.
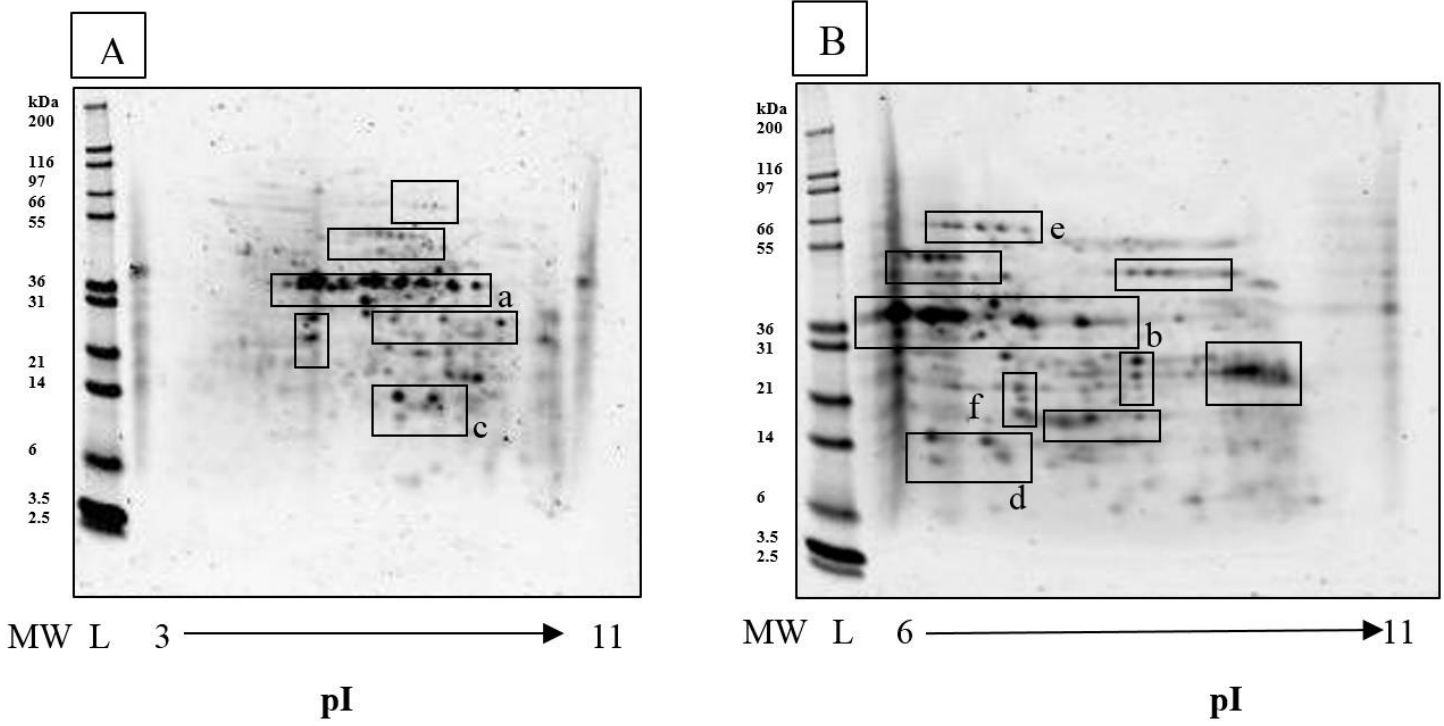

Figure 3 Protein profiles of oat (cv. Valentin)

Legend: A - avenins profile in immobilised $\mathrm{pH}$ gradients strips with $\mathrm{pH} 3-11$, B - avenins profile in immobilised pH gradients strips with $\mathrm{pH}$ 6-11.

MW [kDa] - molecular weight, L - ladder marker; a and b: gluten proteins/avenins family; c and d: alpha-amylase/ trypsin inhibitors family; e: alergen (66 kDa); f: avenin-E.

Rye

Wholemeal rye flour contains high levels of dietary fibre, vitamins, minerals and essential amino acids, all of which have positive health effects. Although rye is closely relate to wheat, which has the unique properties and breadmaking quality largely determined by the gluten proteins, the rye storage proteins are not able to form similar amounts of highly polymerized aggregates. Rye contains about 8 $15 \%$ proteins and hence is important source of them for the nutrition of humans and livestock. The major protein fraction in the grain is defined as prolamins (Gellrich et al., 2003)

Although rye belongs to a similar tribe as wheat and barley quite big differences were observed for the 2-DE protein map of rye (Fig. 4). The other cereals had small number of abundant groups, mainly focussed in the basic regions of the gels however, rye had a higher number of abundant groups visible over a broad range ( 6-200000 Da, pI 4-9). Highly abundant proteins visible at approximately 55000 Da, pI 6-9 (marked as a) and $40000 \mathrm{Da}$, pI 6-9 (marked as b) were observed as over-lapping spots forming an isoelectric streak. These proteins were running at the correct molecular weight and pI observed for HMW and MWM subunits of glutenin (Gellrich et al., 2003). Rocher et al. (Rocher et al., 1996) identified $\gamma$ and $\omega$-type secalins together with two low molecular mass glycoproteins as the major celiac immunoreactive proteins from a chloroform/methanol soluble extract from rye endosperm. One $\omega$-type secalins of $40 \mathrm{kDa}(\omega 1-40)$; three $\gamma$-type secalins one of $70 \mathrm{kDa}(\gamma-70)$ and two of $35 \mathrm{kDa}(\gamma-35)$; as well as two low molecular mass glycoproteins of $15 \mathrm{kDa}$ and $18 \mathrm{kDa}$, all exhibit celiac serum antigenicity. Celiac immunogenic secalins, $\gamma-70, \gamma-35$ and $\omega 1-40$ indicated molecular masses of 71457 $\mathrm{Da}, 32240 \mathrm{Da}$ and $39117 \mathrm{Da}$ respectively. There is absence of information about rye proteins, especially of those obtained by $2-\mathrm{D}$ electrophoresis as well as by oat proteins.

When proteins were separated over a narrow $\mathrm{pH}$ range of $\mathrm{pH}$ 6-11, we found some proteins that were at similar $\mathrm{pI}$ and molecular weight to protein spots separated on wheat 2-DE gels, including isoelectric streaks of protein spots in the region of $55000 \mathrm{Da}$, pI 6-7 and in the region of 45-50000 Da, pI 6-8 (Fig. 4).

Comparison of rye to wheat (Fig. 1), barley (Fig. 2) and oat (Fig. 3) protein profiles showed that each cereal had completely different spot patterns in the LMW region of the gels $(<14000 \mathrm{Da})$, but similarities were observed in the HMW and MMW regions. This is especially evident in the $\mathrm{pH}$ 6-11 gels. 


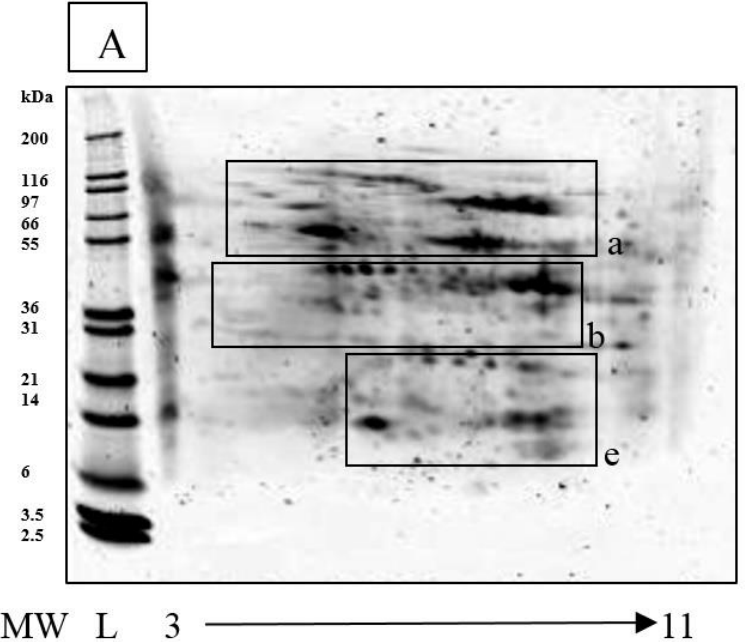

pI

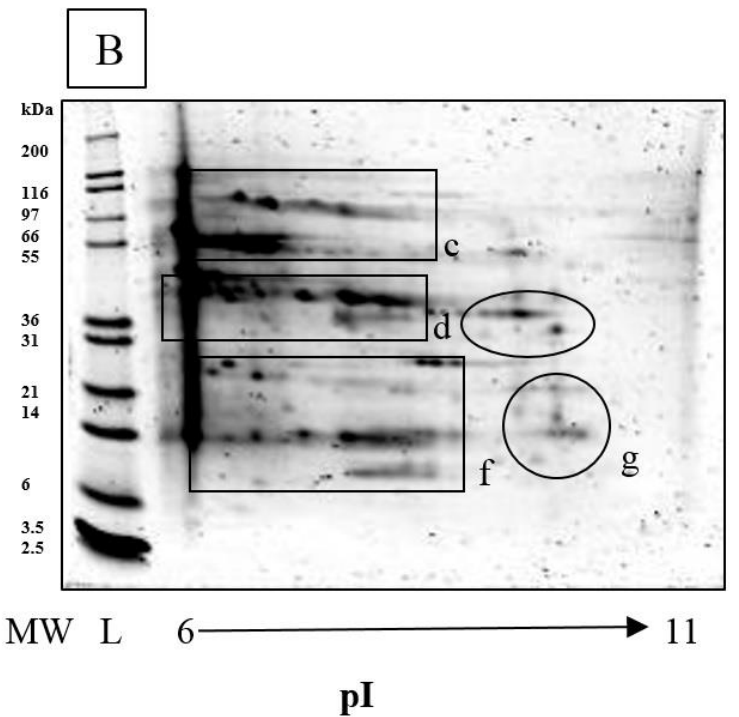

pI

Figure 4 Protein profiles of rye (cv. Oklon)

Legend: A - secalins profile in immobilised $\mathrm{pH}$ gradients strips with $\mathrm{pH} 3-11, \mathrm{~B}$ - secalins profile in immobilised $\mathrm{pH}$ gradients strips with $\mathrm{pH}$ 6-11.

MW [kDa] - molecular weight, L - ladder marker; a and c: high molecular weight subunits of secalins; $b$ and d: medium molecular weight subunits of secalins; e and f: low molecular weight subunits of secalins; g: triticin.

\section{Amaranth}

Upon initial observation, Amaranth has many proteins focussed between $\mathrm{pH}$ 3-11, 25000-200000 Da (Fig. 5) with areas of abundant proteins at: 14000-31000 Da, pI 8-9 (marked as e), $36000 \mathrm{Da}$, pI 4-6 (marked as g), 55000-66000 Da , pI 6-7 (marked as h); this could be $11 \mathrm{~S}$ globulin which has a theoretical pI 6.53, molecular weight $55064 \mathrm{Da}$, and belongs to the $11 \mathrm{~S}$ seed storage protein family. Fewer proteins were observed for the $\mathrm{pH}$ 6-11 gel, especially in the HMW weight region of the gel where storage proteins (marked as a, b) were observed for the cereals Similar results were achieved by Klubicová (Klubicová et al., 2016). This is due to the fact that the pseudocereals are a botanically different species compared to cereal grasses, and even if they are rich in protein, unfavourable fractions are not present or are only available in small amounts.

Klubicová et al. (Klubicová et al., 2016) achieved the best resolution results in the 2-DE using immobilised $\mathrm{pH}$ gradients strips with a $\mathrm{pH}$ range of 5-8. Out of the 461 spots detected, 249 were successfully identified by Liquid chromatographymass spectrometry (LC-MS/MS) analysis, making this the most inclusive protein profile of mature amaranth seed. Unknown proteins represented the most abundant class of proteins (59 proteins), the second most abundant category was related to energy (46 proteins) and then to seed storage proteins (43 proteins).

There is not enough information about 2-DE of pseudocereals available in the literature, so it was difficult to assign any likely protein identifications to the gels.
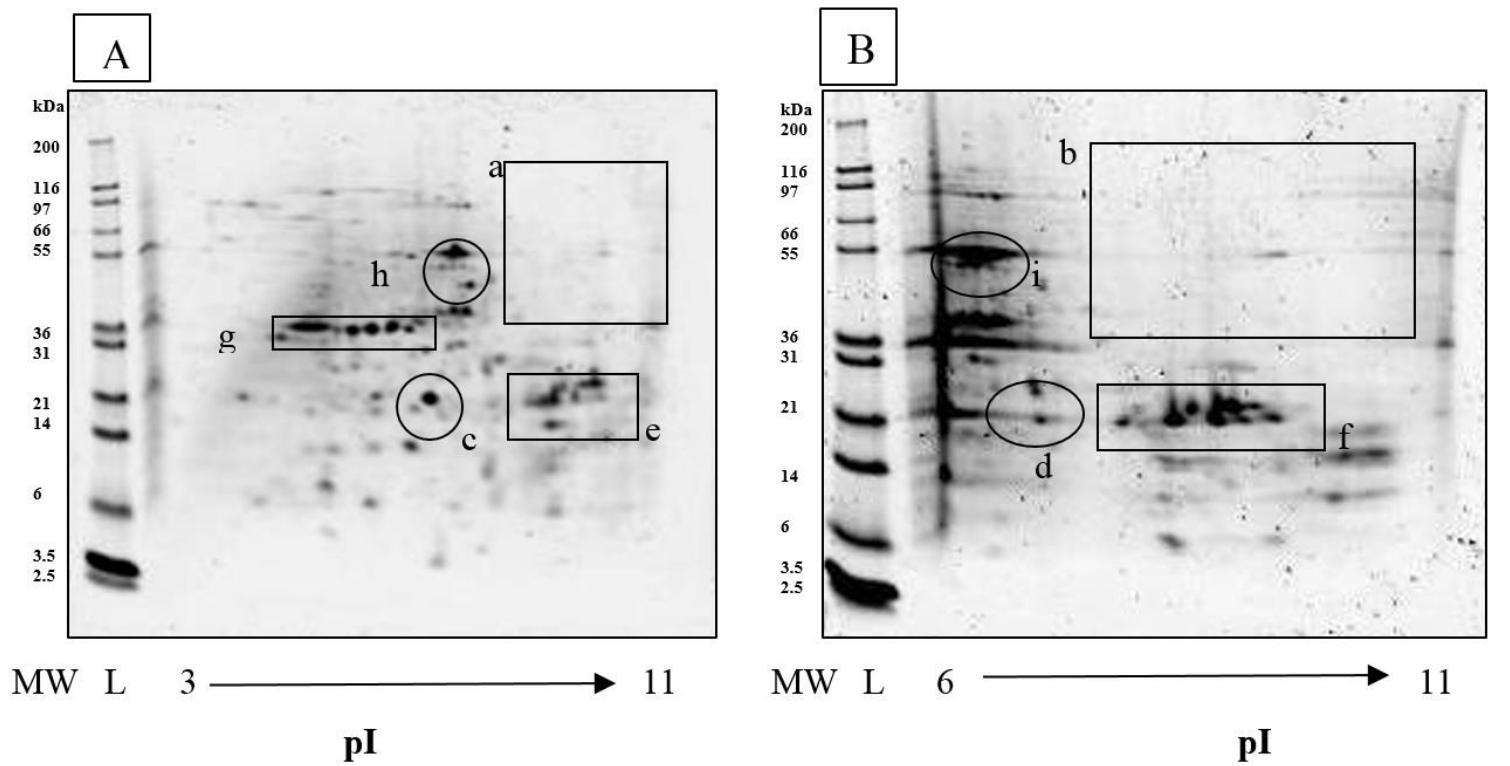

Figure 5 Protein profiles of amaranth (cv. Plainsman)

Legend: A - glutelins profile in immobilised $\mathrm{pH}$ gradients strips with $\mathrm{pH} 3-11, \mathrm{~B}$ - glutelins profile in immobilised $\mathrm{pH}$ gradients strips with $\mathrm{pH}$ 6-11.

MW [kDa] - molecular weight, L - ladder marker; a and b: high molecular weight subunits of glutelins; $\mathrm{c}$ and d: low molecular weight subunits of gutelins; e and f: low molecular weight subunits of gutelins with MW $14 \mathrm{kDa}-31 \mathrm{kDa}$; g: low molecular weight subunits of gutelins with MW $36 \mathrm{kDa}$; h and i: $11 \mathrm{~S}$ globulins with MW $55 \mathrm{kDa}-66 \mathrm{kDa}$

\section{Buckwheat}

uckwheat seeds are rich in proteins with well-balanced amino acid composition, fibres, vitamins and minerals. The proteins of buckwheat are generally recognized as the best-known source of high biological value proteins in the plant kingdom with a high lysine level. The content of flavonoids, a kind of bioactive substance, is also substantial. Treated as a functional food, buckwheat has drawn the attention of the wider world (Aalberse, 2000; Anderson and Wieser, 2006; Zhou et al.,
2018). Buckwheat, among pseudocereals, has gained primary position as a potential source for gluten free food products as well as a rich source of antioxidant compounds (Zhou et al., 2018)

Similar to amaranth, buckwheat has many proteins focussed in the acidic region and fewer in the basic region; of which these proteins appear to be highly abundant (Fig. 6). Also, in comparison to amaranth, the lack of storage proteins in the HMW basic regions of the gels (marked as a, b) was noticeable (molecular weight from 36-200000 Da, pI 7-11). Image analysis showed a higher number of spots on 2-DE 
map of buckwheat when compared to amaranth (Fig. 5). Also, the buckwheat 2 DE map shows spots of protein with higher intensity in the region ranging from 30-45000 Da, pI 5-6 (marked as g) as well as highly abundant protein spots from visible at 36-40000 Da, pI 8-9 (marked as h). We can see some similarities with buckwheat cv. Pyra. For example, protein spots at approximately $21000 \mathrm{Da}, \mathrm{pI} 7$ (Fig. 5 marked as c, d and Fig. 6, marked as c, d), a strip of protein spots in range of pI 8-10, 21000 Da (Fig. 5 marked as e, f and Fig. 6 marked as e, f).

In our study, as expected, the 2-DE protein profiles were different for pseudocereals (compared to cereals); purely because they are a different botanical families (Fig. 1 and Fig. 6). The 2-DE profiles show us that the pseudocereals do not have HMW storage proteins, which are relevant because the lack of these storage proteins indicates that they are suitable as a replacement for cereals for people with $\mathrm{CD}$. There is very little information in the literature about the proteins of pseudocereals, especially 2-DE, therefore it would be worthwhile performing some mass spectrometry to identify them.

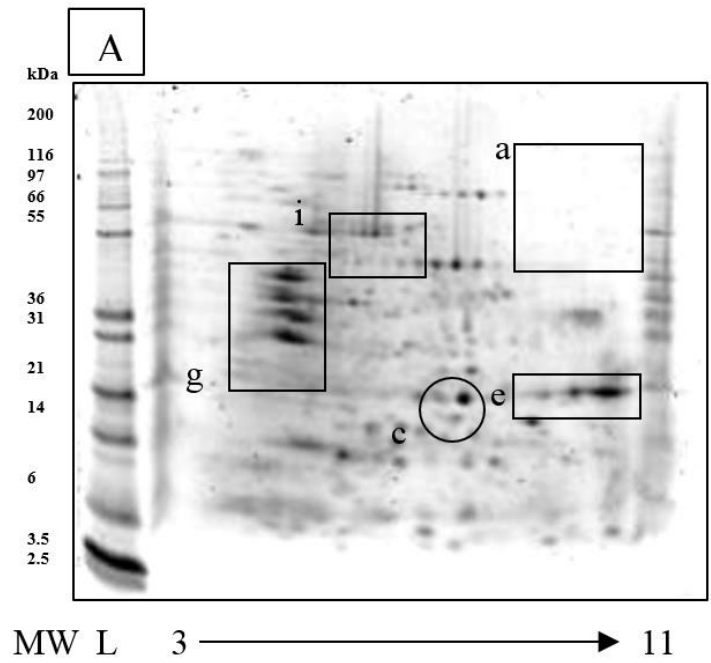

pI
We can notice big differences especially between protein composition of cereals and pseudocereals. On the pseudocereal proteins profiles we miss protein pattern in area with molecular mass ranging from $40 \mathrm{Da}$ to $200000 \mathrm{Da}$ and $\mathrm{pI}$ ranging from 9-11, which are visible on cereal proteins profiles and corresponded to gluten protein, these are supposed triggers of $\mathrm{CD}$. This showed differences between species that also are related to differences in functional properties. On the other hand, we found similarity between the chemical properties of proteins in pseudocereals (amaranth and buckwheat). Most of the extracted proteins had pIvalues ranging from 5 to 10 and the molecular masses ranging from $14 \mathrm{Da}$ to 55000 Da (Fig. 3 and Fig. 6).

For the moment we has not realized mass spectrometry experiments for exact identification protein spots, as well as using sera from celiac patients to identify problem proteins, but it belongs to our future plans.

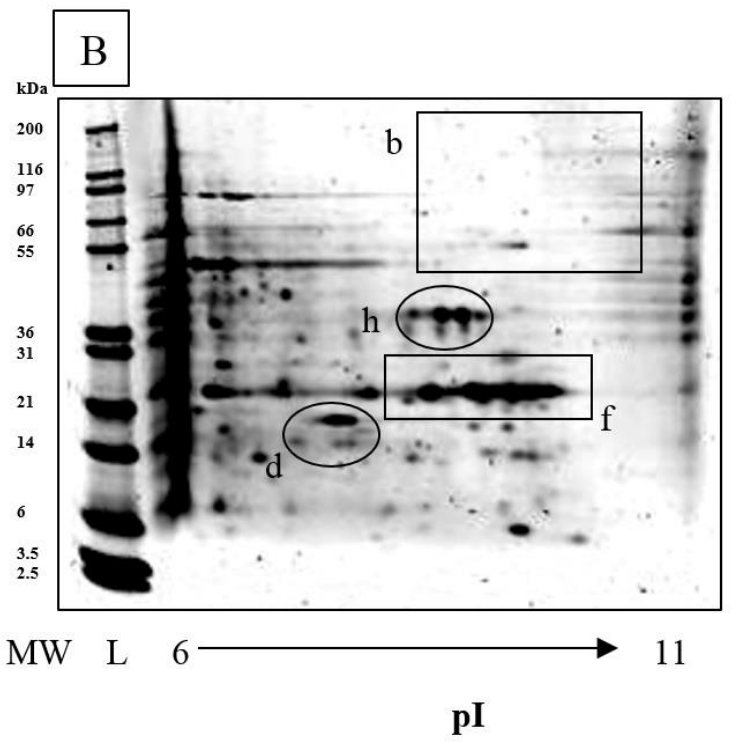

Figure 6 Protein profiles of buckwheat (cv. Pyra)

Legend: A - glutelins profile in immobilised $\mathrm{pH}$ gradients strips with $\mathrm{pH} 3-11, \mathrm{~B}$ - glutelins profile in immobilised $\mathrm{pH}$ gradients strips with $\mathrm{pH}$ 6-11.

MW [kDa] - molecular weight, L - ladder marker; a and b and i: high molecular weight subunits of glutelins with MW $36 \mathrm{kDa}-200 \mathrm{kDa}$; $\mathrm{c}$ and d: low molecular weight subunits of gutelins with MW $21 \mathrm{kDa}$; e and f: low molecular weight subunits of gutelins with MW $21 \mathrm{kDa}$; g and h: low molecular weight subunits of gutelins with MW $30 \mathrm{kDa}-45 \mathrm{kDa}$.

\section{CONCLUSION}

Our work has dealt with comparisons of proteins profiles of individual plan species, finding out differences between them and between cereals and pseudocereals by 2-DE. The consequential data consist of 2-DE images of extracted proteins obtained for six different cereal and pseudocereal species. First, 2-DE - gels with $\mathrm{pH}$ 3-11 were run, that were followed by 2-DE - gels with $\mathrm{pH} 3$ 11. The chemical properties of cereal proteins except oat were very similar. On the other hand, we has found similarity between the chemical protein properties of pseudocereals amaranth and buckwheat. The proteins profiles of oat was much more in accordance with protein profiles of pseudocereals compare to cereals. This showed differences between species that also are related to differences in functional properties. The two dimensional protein profiles can be beneficial in many ways. 2DE protein profiles can be used as a basis for the mass spectrometry LC-MS / MS method, which can accurately identify a specific allergen in the raw materials and then recommend the most appropriate diet for patients suffering from food intolerance.

Acknowledgments: This study was financially supported by VEGA project No. 1/0246/18, VEGA project No. 2/0109/19 and KEGA project No. 025SPU4/2018.

\section{REFERENCES}

Aalberse, R. C. (2000). Structural biology of allergens. Journal of Allergy and Clinical Immunology, 106(2), 228-238. https://doi.org/10.1067/mai.2000.108434 Akagawa, M., Handoyo, T., Ishii, T., Kumazawa, S., Morita, N., Suyama, K (2007). Proteomic analysis of wheat flour allergens. Journal of Agriculture and Food Chemistry, 55(17), 6863-6870. https://doi.org/10.1021/jf070843a

Anderson, R. P., Wieser, H. (2006). Medical application of gluten-composition knowledge. In: Wrigley, C. - Bekes, F. - Bushuk, W. (Eds.): Gliadin and glutenin the unique balance of wheat quality. St. Paul : AACC International, 387-409. ISBN: 978-1-891127-51-9.

Bak-Jensen, K., Laugesen, S., Roepstorff, P., Svensson, B. (2004). Twodimensional gel electrophoresis pattern $(\mathrm{pH} \mathrm{6-11)}$ and identification of watersoluble barley seed and malt proteins by mass spectrometry. Proteomics, 4(3), 728742. https://doi.org/10.1002/pmic.200300615
Bradford, M. M. (1976). A rapid and sensitive method for the quantitation of microgram quantities of protein utilizing the principle of protein-dye binding. $\begin{array}{lll}\text { Analytical } & \text { Biochemistry, } & \text { 72(1-2), }\end{array}$ https://doi.org/10.1006/abio.1976.9999

DOI: $10.1126 /$ science. 1068275 .

Dupont, F. M., Vensel, W. H., Tanaka, Ch. K., Hurkman, W. J., Altenbach, S. B. (2011). Deciphering the complexities of the wheat flour proteome using quantitative two-dimensional electrophoresis, three proteases and tandem mass spectrometry. Proteome Science, 9:10. https://doi.org/10.1186/1477-5956-9-10

Finnie, Ch., Melchior, S., Roepstorff, P., Svensson, B. (2002). Proteome analysis of grain filling and seed maturation in barley. Plant Physiology, 129, 1308-1319. https://doi.org/10.1104/pp.003681

Gellrich, C., Schieberle, P., Wieser, H. (2003). Biochemical characterisation and quantification of the storage protein (secalin) typesin rye flour. Cereal Chemistry, 80(1),102-109. https://doi.org/10.1094/cchem.2003.80.1.102

Gorinstein, S., Drzewiecki, J., Delgado-Licon, E., Pawelzik, E., Ayala, A. L. M., Medina, O. J., Haruenkit, R., Trakhtenberg, S. (2005). Relationship between dicotyledone-amaranth, quinoa, fagopyrum, soybean and monocots-sorghum and rice based on protein analyses and their use as substitution of each other. Journal of European Food Research and Technology, 221(1), 69-77. https://doi.org/10.1007/s00217-005-1208-2

Gorinstein, S., Pawelzik, E., Delgano-Licon, E., Haruenkit, R., Weisz, M. Trakhtenberg, S. (2002). Characterization of pseudocereals and cereals proteins by protein and amino acid analyses. Journal of the Science of Food and Agriculture, 82(8), 886-891. https://doi.org/10.1002/jsfa.1120

Guo, B., Luan, H., Lin, S., Lv, Ch., Zhang, X., Xu, R. (2016). Comparative proteomic: Analysis of two barley cultivars (Hordeum vulgare L.) with contrasting grain protein content. Frontiers in Plant Science, 7, 542. https://doi.org/10.3389/fpls.2016.00542.

Gupta, H. O. (2004). Improving the nutritional quality of maize after suplementation with processed soybean. Journal of Food Science and Technology, 41(2), 167-170.

Hurkman, W. J., Tanaka, CH. K. (2004). Improved methods for separation of wheat endosperm proteins and analysis by two-dimensional gel electrophoresis Journal of Cereal Science. 40(1), 295-299. https://doi.org/10.1016/j.jcs.2004.09.001 
Jackson, E. A., Holt, L. M., Payne, P. I. (1983). Characterisation of high molecular weight gliadin and low molecular weight glutenin subunits of wheat endosperm by two dimensional electrophoresis and the chromosomal localisation of their controlling genes. Theoretical and Applied Genetics, 66(1), 29-37. https://doi.org/10.1007/bf00281844

James, J. M., Sixbey, J. P., Helm, R. M., Bannon, G. A., Burks, A.W. (1997). Wheat $\alpha$-amylase inhibitor: A second route of allergic sensitization. Journal of allergy and Clinical Immunology, 99(2), 239-244. https://doi.org/10.1016/S00916749(97)70103-9.

Klubicová, K., Szabová, M., Škultéty, L., Libiaková, G., Hricová, A. (2016) Revealing the seed proteome of the health benefitting grain amaranth (Amaranthus $\begin{array}{llll}\text { cruentus L.). } & \text { Chemical Papers, } & \text { 70(10), } & \text { 1322-1335. }\end{array}$ https://doi.org/10.1515/chempap-2016-0065

Londono, D. M., Van’t Westende, W. P. C., Goryunova, S., Salentijn, E. M. J., Van Den Broeck, H. C., Van Der Meer, I. M., Visser, R. G. F. Gilissen, L. J. W. J., Smulders, M. J. M. (2013). Avenin diversity analysis of the genus avena (oat) Relevance for people with celiac disease. Journal of Cereal Science, 58(1), 170177. https://doi.org/10.1016/j.jcs.2013.03.017

Ludvigsson, J. F., Rubio-Tapia, A., Van Dyke, C. T., Melton, L. J., Zinsmeister, A. R., Lahr, B. D., Murray, J. A. (2013). Increasing incidence of celiac disease in a North American population. American Journal of Gastroenterology, 108(5), 818824. https://doi.org/10.1038/ajg.2013.60

Malalgoda, M., Simsek, S. (2017). Celiac disease and cereal proteins. Food Hydrocolloids, 68, 108-113. https://doi.org/10.1016/j.foodhyd.2016.09.024

Nałęcz, D., Szerszunowicz, I., Dziuba, M., Minkiewicz, P. (2017). 2-DE Separation and identification of oat (Avena sativa L.) proteins and their prolamin fractions. In: Gasparis S. (eds) Oat. Methods in molecular biology, 1536. New York : Humana Press, 235-251. ISBN: 978-1-4939-6680-6 (print), 978-1-49396682-0 (online). https://doi.org/10.1007/978-1-4939-6682-0_17

Østergaard, O., Finnie, Ch., Laugesen, S., Roepstorff, P., Svensson, B. (2004) Proteome analysis of barley seeds: Identification of major proteins from twodimensional gels (pI4-7). Proteomics, 4(8), 2437-2447. https://doi.org/10.1002/pmic.200300753

Parnell, N. D. J., Ciclictira, P. J. (1999). Rerview article: Celiac disease and its management. Alimentary Pharmacology and Therapeutics, 13(1), 1-13. https://doi.org/10.1046/j.1365-2036.1999.00448.x

Perrocheau, L., Rogniaux, H., Boivin, P., Marion, D. (2005). Probing heat-stable water-soluble proteins from barley to malt and beer. Proteomics, 5(11), 2849-2858. https://doi.org/10.1002/pmic.200401153

Rocher, A., Calero, M., Soriano, F., Méndez, E. (1996). Identification of major rye secalins as celiac immunoreactive proteins. Biochimica et Biophysica Acta, 1259(1), 13-22. https://doi.org/10.1016/0167-4838(95)00269-3

Rocher, A., Colilla, F., Ortiz, M. L., Mendez, E. (1992). Identification of three major celiac immunoreactive proteinsand one $\alpha$-amylase inhibitor from oat endosperm. FEBS letters, 310(1), 37-40. https://doi.org/10.1016/00145793(92)81141-8

Salt, L. J., Robertson, J. A., Jenkins, J. A., Mulholland, F., Mills, E. N. C. (2005)

The identification of foam-forming soluble proteins from wheat (Triticum aestivum) dough. $\quad$ Proteomics, 5(6), 1612-1623. https://doi.org/10.1002/pmic.200401035

Shewry, P. R., Beaudoin, F., Jenkins, J., Griffiths-Jones, S., Mills, E. N. C. (2002) Plant protein families and their relationships to food allergy. Biochemical Society Transactions, 30(6), 906-910. https://doi.org/10.1042/bst0300906

Shewry, P. R., D Ovidio, R., Lafiandra, D., Jenkins, J. A., Mills, E. N. C., Békés, F. (2009). Wheat grain proteins. In: Khan, K., Shewry, P. R.: Wheat: Chemistry and technology. 4th edition. Minnesota: AACC International Press,.223-298. ISBN 978-1-891127-55-7.

Shewry, P. R., Halford, N. G., Tatham, A. S. (1992). High molecular weight subunits of wheat glutenin. Journal of Cereal Science, 15(2), 105-120. https://doi.org/10.1016/s0733-5210(09)80062-3

Shewry, P. R. (2006). Improving the protein content and quality of temperate cereals: wheat, barley and rye. In: Impacts of agriculture on human health and nutrition. Vol. II, In: UNESCO - Encyclopedia of Life Support Systems (UNESCO-EOLSS) [online]. Paris : EOLSS Publishers, revised 2006 [cited 14 May 2019]. 〈https://www.eolss.net/Sample-Chapters/C10/E5-21-04-04.pdf>

Skylas, D. J., Mackintosh, J. A., Cordwell, S. J., Basseal, D. J., Walsh, B. J., Harry, J., Blumenthal, C., Copeland, L., Wrigley, C. W., Rathmell, W. (2000). Proteome approach to the characterisation of protein composition in the developing and mature wheat-grain endosperm. Journal of Cereal Science, 32(2), 169-188. https://doi.org/10.1006/jcrs.2000.0321

Varjonen, E., Savolainen, J., Mattila, L., Kalimo, K. (1994). IgE-binding components of wheat, rye, barley and oats recognized by immunoblotting with sera from adult atopic dermatitis patients. Clinical and Experimental Allergy, 24(5), 481-489. https://doi.org/10.1111/j.1365-2222.1994.tb00938.x

Vensel, W. H., Tanaka, Ch. K., Altenbach, S. B. (2014). Protein composition of wheat gluten polymer fractions determined by quantitative two-dimensional gel electrophoresis and tandem mass spectrometry. Proteome Science, 12(1), 8 https://doi.org/10.1186/1477-5956-12-8

Wieser, H., Koehler, P. (2008). The biochemical basis of celiac disease. Cereal Chemistry, 85(1), 1-13. https://doi.org/10.1094/cchem-85-1-0001
Zhou, M., Tang, Y., Deng, X., Ruan, C., Kreft, I., Tang, Y., Wu, Y. (2018) Overview of buckwheat resources in the world. In: ZHOU, M., KREFT, I., SUVOROVA, G., TANG, Y., WOO, S. H. (Eds.): Buckwheat germplasm in the world London : Academic Press, 2018, 1-7. ISBN: 9780128110065 (print), 9780128110072 (ebook). https://doi.org/10.1016/b978-0-12-811006-5.00001-x 